\title{
Mutations in BRCA1, BRCA2 and other breast and ovarian cancer susceptibility genes in Central and South American populations
}

\author{
Lilian Jara ${ }^{1,3^{*}}$, Sebastian Morales ${ }^{1}$, Tomas de Mayo ${ }^{1,2,3}$, Patricio Gonzalez-Hormazabal ${ }^{1}$, Valentina Carrasco ${ }^{1}$ \\ and Raul Godoy ${ }^{1}$
}

\begin{abstract}
Breast cancer (BC) is the most common malignancy among women worldwide. A major advance in the understanding of the genetic etiology of $B C$ was the discovery of BRCA1 and BRCA2 (BRCA1/2) genes, which are considered high-penetrance $B C$ genes. In non-carriers of $B R C A 1 / 2$ mutations, disease susceptibility may be explained of a small number of mutations in BRCA1/2 and a much higher proportion of mutations in ethnicity-specific moderate- and/or low-penetrance genes. In Central and South American populations, studied have focused on analyzing the distribution and prevalence of BRCA1/2 mutations and other susceptibility genes that are scarce in Latin America as compared to North America, Europe, Australia, and Israel. Thus, the aim of this review is to present the current state of knowledge regarding pathogenic BRCA variants and other $B C$ susceptibility genes. We conducted a comprehensive review of 47 studies from 12 countries in Central and South America published between 2002 and 2017 reporting the prevalence and/or spectrum of mutations and pathogenic variants in BRCA1/2 and other BC susceptibility genes. The studies on BRCA1/2 mutations screened a total of 5956 individuals, and studies on susceptibility genes analyzed a combined sample size of 11,578 individuals. To date, a total of 190 different BRCA1/2 pathogenic mutations in Central and South American populations have been reported in the literature. Pathogenic mutations or variants that increase $B C$ risk have been reported in the following genes or genomic regions: ATM, BARD1, CHECK2, FGFR2, GSTM1, MAP3K1, MTHFR, PALB2, RAD51, TOX3, TP53, XRCC1, and 2935.
\end{abstract}

Keywords: Hereditary and early onset breast cancer, Susceptibility genes, Pathogenic point mutations, Large genomic rearrangements, Ethnic composition

\section{Background}

Breast cancer $(\mathrm{BC})$ is the most common malignancy among women worldwide. Each year, 1.15 million new cases are diagnosed, representing $23 \%$ of all cancer diagnoses among women [1,2], and one in eight women will develop $\mathrm{BC}$ during their lives [3]. The greatest challenge currently facing clinical researchers, therefore, is identifying prevention strategies that would reduce the morbidity and mortality associated with the disease.

\footnotetext{
*Correspondence: ljara@uchile.cl

${ }^{3}$ Laboratorio de Genética Molecular Humana, Facultad de Medicina, Instituto de Ciencias Biomédicas (ICBM), Programa de Genética, Universidad de Chile, Independencia 1027, Santiago, Chile

Full list of author information is available at the end of the article
}

Breast cancer (BC) is a complex disease, with both sporadic and familial presentations, as in most cancers. Inherited genetic risk factors contribute to $\mathrm{BC}$ susceptibility in both familial and sporadic BC.

The discovery of tumor suppressor genes BRCA1 (MIM 113705) and BRCA2 (MIM 600185) [4, 5] was a major advance in elucidating the genetic etiology of $\mathrm{BC}$. A mutation that inactivates the BRCA proteins increases the risk for breast, ovarian, and other cancers. These genes are now considered high-penetrance dominant autosomal genes for BC susceptibility. Germline mutations in BRCA1 and BRCA2 are responsible for about $25 \%$ of the risk for familial BC [6-8] and therefore $5-10 \%$ of all BC cases [9]. Retrospective studies [10-19], suggest an estimated cumulative risk of breast cancer to 70 years 
of age of $40-87 \%$ for $B R C A 1$ carriers and $27-84 \%$ for $B R C A 2$ carriers. The corresponding ovarian cancer risks are $16-68 \%$ for $B R C A 1$ carriers and $11-30 \%$ for $B R C A 2$ carriers. Disease-causing mutations are distributed throughout the entire coding regions of both genes. Since the identification of $B R C A 1 / 2$ as the principal genes responsible for inherited $\mathrm{BC}[5,20]$, over 3781 distinct DNA sequence variants have been added to the BIC database (http://research.nhgri.nih.gov/bic/). Of these, 3079 are classified as pathogenic, including 1598 truncating mutations (1197 frameshift and 387 nonsense) and 14 splicing alterations. The frequency of BRCA1/2 mutations varies significantly according to geographic region and ethnicity.

There is a consensus that mutations in genes BRCA1/2 and TP53 are responsible for on average $16-20 \%$ of the risk for familial BC $[6,7]$. Genome-wide linkage analyses using large samples of BRCA1/2-negative families have not mapped any other high-penetrance susceptibility loci to date [21]. Therefore, a large part of the genetic component remains unidentified. How can the remaining 80\% of familial BC risk be explained? Ford et al. [15] proposed that other susceptibility alleles, called moderate- or lowpenetrance, could be responsible for a significant percentage of $\mathrm{BC}$ in BRCA1/2-negative families. Currently, $\mathrm{BC}$ risk variants can be classified into three categories of penetrance (high, moderate, and low) that reflect the probability of developing the disease [22]. Therefore, in non-carriers of BRCA1/2 mutations, disease susceptibility may be explained by mutations in other high-, moderate- or low-penetrance genes, interactions between alleles involved in the same pathways, or environmental factors. Sporadic BC is the result of serial stepwise accumulation of acquired and uncorrected mutations in somatic genes that are yet to be identified [23]. Nevertheless, in cases without a family history of BC (sporadic $\mathrm{BC})$, certain combinations of low-penetrance alleles that are associated with a high polygenic risk score (PRS) have been shown to contribute to BC susceptibility [22].

Screening for BRCA1 and BRCA2 mutations provides potentially significant health benefits. Armed with genetic results, physicians may offer risk-reducing options for mutation carriers who have, thus far, not developed cancer, such as prophylactic mastectomy and oophorectomy, prophylactic tamoxifen, or surveillance [24-28].

Research evaluating the distribution and prevalence of BRCA1/2 mutations in Central and South American populations has been quite limited as compared to the number of studies in North America, Europe, Australia and Israel. Moreover, some of the studies performed in Latin America have analyzed hereditary $\mathrm{BC}$, while others have evaluated early-onset $\mathrm{BC}$ or cohorts unselected for family history. Furthermore, because Central and South American populations are of mixed ethnic origin, the distributions of recurrent mutations vary by region and country. Published data regarding other $\mathrm{BC}$ susceptibility genes is even scarcer than data on BRCA $1 / 2$ mutations. Therefore, the aim of this review is to provide a report on the current state of knowledge regarding pathogenic point mutations and large genomic rearrangements (LGRs) in BRCA1 and BRCA2, as well as mutations in other BC susceptibility genes, in Central and South American populations.

\section{Methods}

PubMed, EBSCO, and SciELO databases were searched for all studies involving BRCA1 and BRCA2 mutations in Central and South American individuals with breast cancer. Moreover, we searched for pathogenic mutations or variants in other susceptibility genes in the same populations. The search terms included "hereditary breast cancer;" "South America," "Latin America," and other terms associated with Central or South American countries; and "BRCA1 and BRCA2" and "genes and breast cancer risk." Manuscripts published through February 28, 2017 were considered. Only papers published in English or Spanish were reviewed. Non-human studies, in vitro or in vivo studies, and studies focused on topics other than breast/ovarian cancer were excluded.

The inclusion criteria varied significantly among the selected studies; therefore, we classified the articles into three categories: cohorts that included cases with hereditary BC (cohort A), cases with early-onset ( $\leq 40$ years) $\mathrm{BC}$ (cohort $\mathrm{B}$ ), and cases unselected for family history of $\mathrm{BC}$ (cohort C). We classified a cohort as hereditary BC (cohort A) if the inclusion criteria met one or more of the following criteria, as established in the literature: (1) At least two first-degree relatives with $\mathrm{BC}$ and/or ovarian cancer diagnosed at any age; (2) at least two first- or second-degree relatives with $\mathrm{BC}$ diagnosed before the age of 50 years; (3) at least three first- or second-degree relatives with $\mathrm{BC}$ with at least one diagnosed before the age of 40 ; (4) at least one relative with BC diagnosed before the age of 50 and at least one relative with ovarian cancer diagnosed at any age; (5) at least one male relative with $\mathrm{BC}$ diagnosed at any age and at least one female relative diagnosed with $\mathrm{BC}$ at any age; (6) at least one relative diagnosed with $B C$ before the age of 30 and one other first- or second-degree relative diagnosed with $\mathrm{BC}$ at any age; and (7) at least one relative with bilateral $\mathrm{BC}$ and one other first- or second-degree relative with BC. A cohort was classified as early-onset BC (cohort B) if the cohort was made up entirely of $\mathrm{BC}$ patients diagnosed at or before 40 years of age. We classified a cohort as unselected for 
family history (cohort C) if none of the criteria for hereditary BC were applied in the case selection.

Pathogenic mutations are base substitutions, deletions, or duplications that inactivate the BRCA proteins. "Recurrent" refers to mutations present in several cases in at least one cohort.

\section{The scope of BRCA1 and BRCA2 mutations in Central and South American countries}

We conducted a literature review of reports on $B R C A 1$ and $B R C A 2$ pathogenic point mutations and LGRs in 12 Central and South American countries (Argentina, Bolivia, Brazil, Chile, Colombia, Costa Rica, Ecuador, Mexico, Paraguay, Peru, Uruguay and Venezuela). Between January 2002 and February 2017, there were 28 published reports on BRCA mutations in these countries. Figure 1 shows that studies were performed in nine countries: Argentina, Brazil, Colombia, Costa Rica, Chile, Mexico, Peru, Uruguay and Venezuela. There were no reports on BRCA mutations in Bolivia, Ecuador or Paraguay. Collectively, the 28 studies screened 5956 individuals and identified 190 different pathogenic mutations (Additional file 1: Table S1; Tables 1,2).

Additional file 1: Table S1; Tables 1 and 2 show the cohort size, inclusion criteria, and $B R C A$ pathogenic point mutations, $\operatorname{LGR}(\mathrm{s})$ and recurrent mutations detected in cohorts A, B and C, respectively. Additional file 1: Table S1 show that in hereditary BC, 118 different BRCA point mutations were detected in 9 countries $(68$ in BRCA1 and 50 in BRCA2). Recurrent mutations were detected in Argentina, Chile, Brazil, Colombia and Costa Rica. Table 1 shows that in early-onset BC, 21 different
$B R C A$ mutations were detected in Brazil and Mexico (13 in BRCA1 and 8 in BRCA2). The c.5266dupC and c.548?_4185+?del mutations were recurrent in Brazil and Mexico, respectively. Table 2 shows that in cohorts unselected for family history, 51 different $B R C A$ mutations (29 in BRCA1 and 22 in BRCA2) were detected in Brazil, Colombia, Mexico and Peru. Large genomic rearrangements were reported in Argentina, Brazil, Chile, Mexico and Peru.

When the results were analyzed separately for each country, we found that 57 different $B R C A$ mutations were detected in Argentina (32 in BRCA1 and 25 in BRCA2), all in hereditary $B C$ cohorts $(\mathrm{n}=40)$, including 4 recurrent mutations ( 2 in $B R C A 1$ and 2 in $B R C A 2$ ). Four LGRs were reported in BRCA1 but none in BRCA2 [29].

In Brazil, 6 studies that collectively screened 1151 individuals with hereditary $\mathrm{BC}$ reported 34 different $B R C A$ mutations (24 in BRCA1 and 10 in BRCA2) [30-35], including 7 recurrent mutations (5 in BRCA1 and 2 in $B R C A 2$ ) (Additional file 1: Table S1). In cohort $\mathrm{B}$, a study by Carraro et al. [36] $(\mathrm{n}=54)$ detected another 5 mutations ( 2 in BRCA1 and 3 in BRCA2), including the recurrent mutation c.5266dupC (3.7\%), which was also a recurrent mutation in hereditary $\mathrm{BC}$ (Additional file 1: Table S1). Another 3 mutations not seen in cohorts A or $\mathrm{B}$ were detected in cohort $\mathrm{C}(\mathrm{n}=402)(1$ in BRCA1 and 2 in $B R C A 2$ ), including the recurrent mutation c.6405_6409delCTTAA (0.5\%) [37]. Therefore, 42 different pathogenic point mutations in $B R C A$ were described in the cohorts $\mathrm{A}, \mathrm{B}$ and $\mathrm{C}$ in Brazil. All patients positive for $B R C A$ mutations had a family history of BC (Additional file 1: Table S1; Tables 1, 2). Four different LGRs

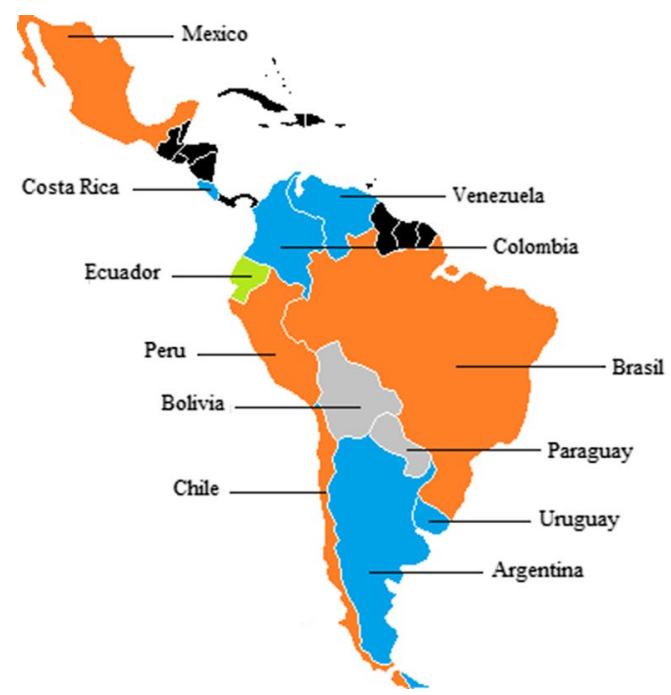

Countries with $\mathrm{BRCA} 1 / 2$ studies

4 Countries with BRCA1/2 and other susceptibility mutations studies

1 Countries with other susceptibility mutations studies

2 Countries without BRCA1/2 and other susceptibility mutations studies

Fig. 1 The scope of $B R C A 1$ and $B R C A 2$ mutations in Central and South American countries. In total 12 countries were evaluated. No $B R C A$ mutation studies were found in Bolivia, Paraguay and Ecuador (the latter only with other susceptibility alleles) 


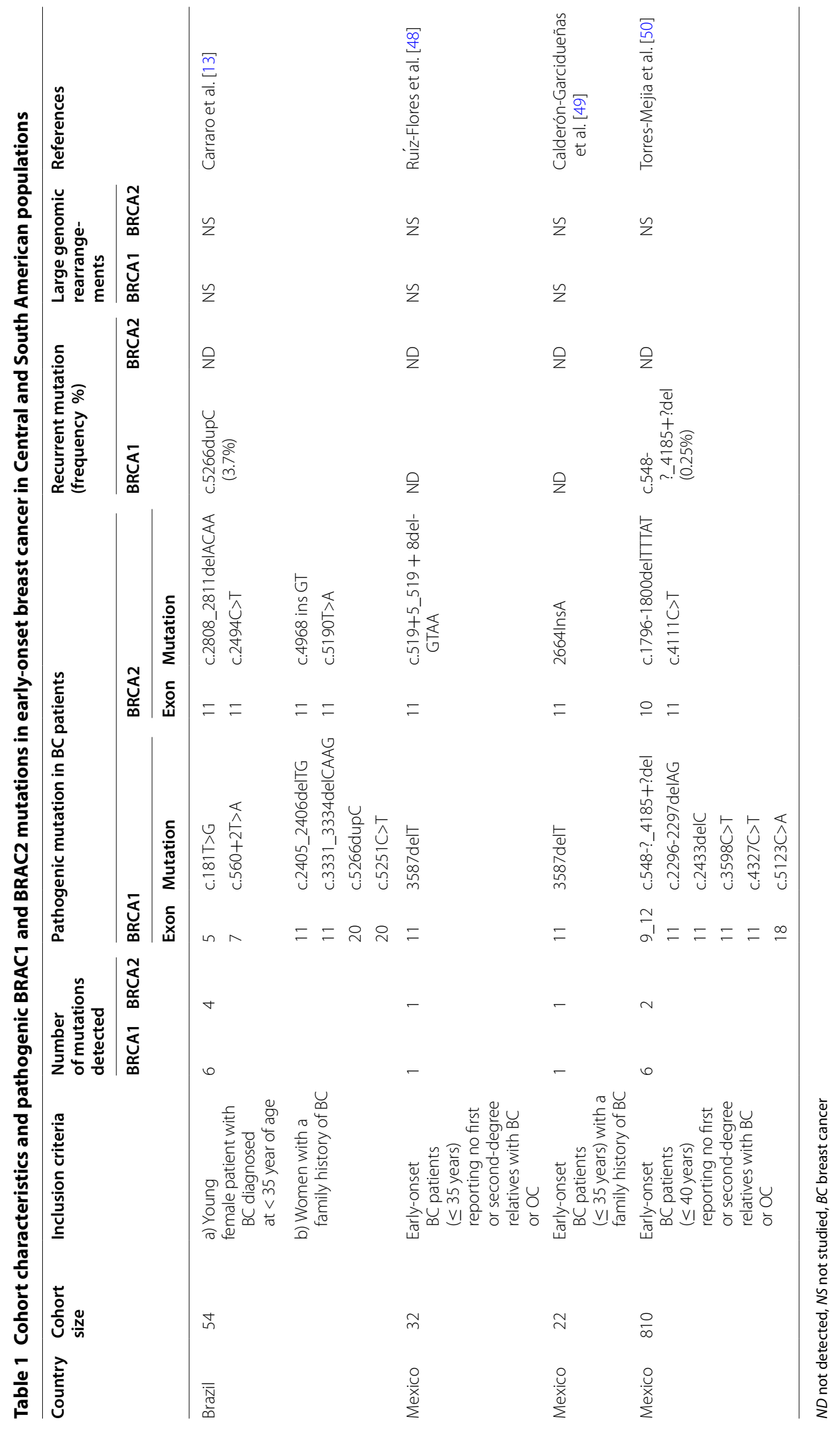




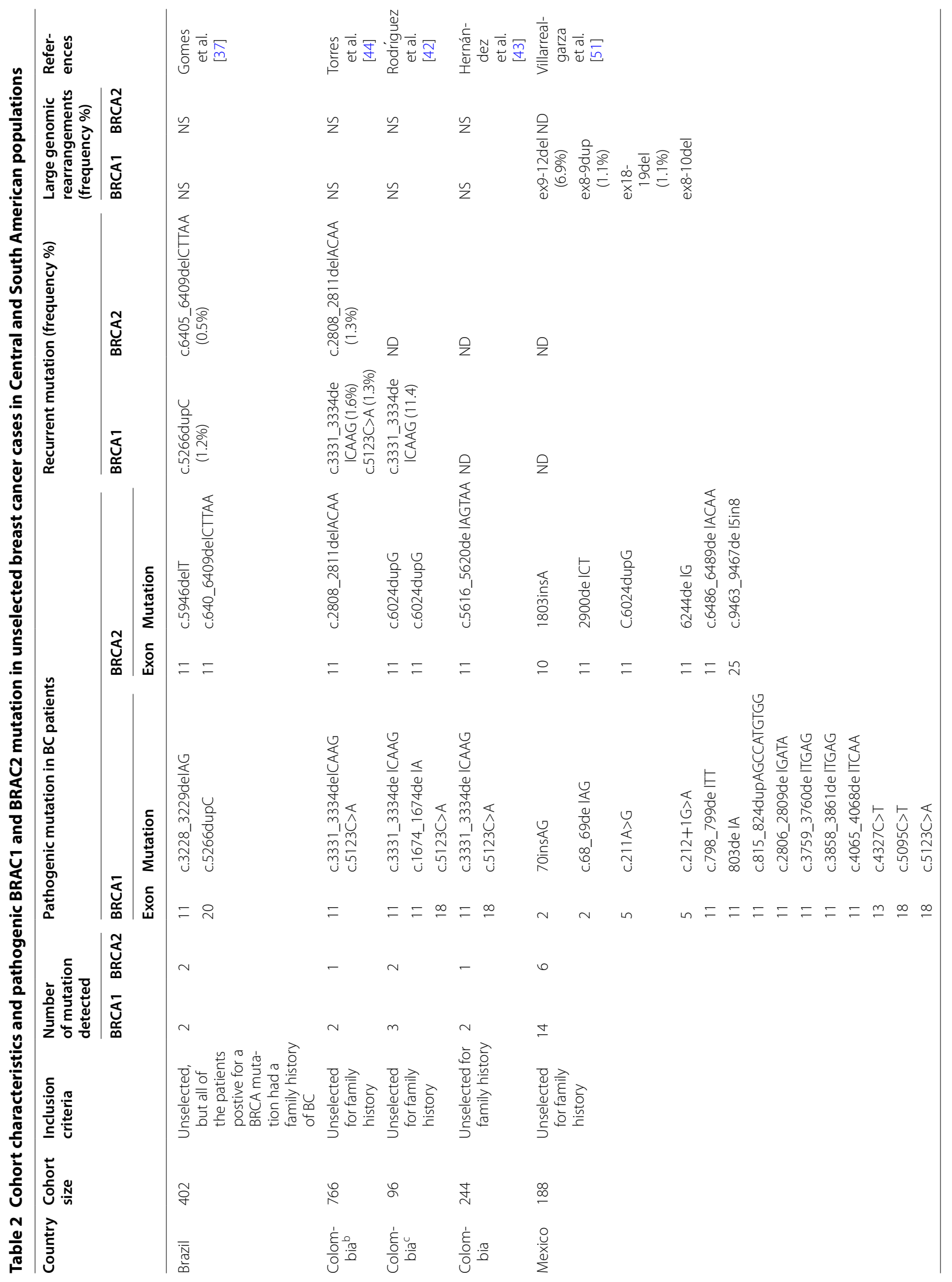




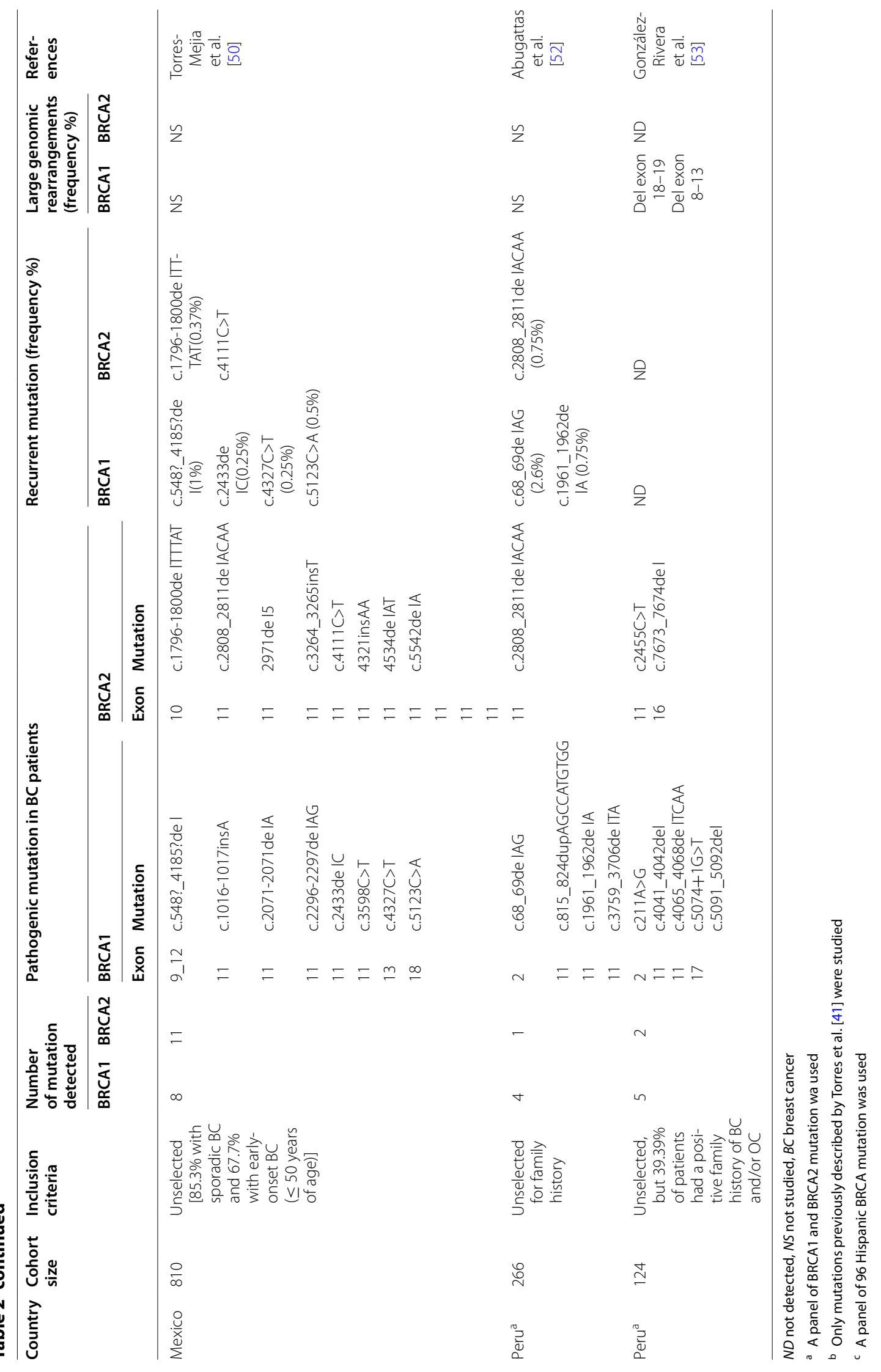


(3 in BRCA1 and 1 in BRCA2) were also reported, all in hereditary $\mathrm{BC}$, one of which was recurrent (Additional file 1: Table S1).

In Chile, 19 BRCA mutations were reported (9 in $B R C A 1$ and 10 in $B R C A 2)$, all in hereditary $\mathrm{BC}$. Of these, 9 were recurrent (4 in $B R C A 1$ and 5 in BRCA2) (Additional file 1: Table S1) [38, 39]. Furthermore, 2 LGRs were detected in cohort A [40]. No BRCA mutations were reported in cohorts B or C.

The only study on patients with hereditary $\mathrm{BC}$ in Colombia $(\mathrm{n}=53)$ described 6 BRCA mutations (2 in $B R C A 1$ and 4 in $B R C A 2), 2$ of which were recurrent in BRCA1 (c.3331_3334delCAAG and c.5123C >A) and one of which was recurrent in $B R C A 2$ (c.2808_2811delACAA) (Additional file 1: Table S1) [41]. Another 3 studies that collectively screened 1106 patients unselected for family history described another 4 mutations (1 in BRCA1 and 3 in BRCA2) [42-44]. Table 3 shows the mutations that were reported in more than one cohort. No LGR studies were performed in Colombia. Therefore, in the Colombian population, 10 different pathogenic point mutations in BRCA were detected, 3 of which were recurrent (Additional file 1: Table S1 and Table 2), and no LGR studies were available.

Only one study reported on $B R C A$ mutations in Costa Rica. This study described 4 mutations (1 in BRCA1 and 3 in BRCA2) in a heredity $\mathrm{BC}$ cohort $(\mathrm{n}=111)$, including the recurrent mutation c.5303_5304delTT (1.8\%) [45].

In Mexico, 17 different $B R C A$ mutations were reported in hereditary BC (10 in BRCA1 and 7 in BRCA2). Three LGRs were also described. The authors did not report recurrent mutations $[46,47]$. In cohort $B, 11$ mutations were described (7 in BRCA1 and 4 in BRCA2) [48-50]. Of these, 4 mutations in BRCA1 (c.548-?_4185+?del, c.2296-2297delAG, c.3598C $>\mathrm{T}$ and c.4327C $>\mathrm{T}$ ) and 3 in BRCA2 (c.519+5_519+8delGTAA, c.1796-1800delTTTAT and c.4111C $>\mathrm{T}$ ) were present in women with earlyonset $\mathrm{BC}$ and no family history of the disease $[48,50]$. In the Mexican patients unselected for family history, 36 different $B R C A$ mutations were described (20 in BRCA1 and 16 in $B R C A 2)[50,51]$. Of these, 12 were also present in cohorts $A$ or $B$ (Table 3). In cohort $C, 6$ point mutations were recurrent (4 in BRCA1 and 2 in BRCA2), including c.548-?.4185+?del, which was also a recurrent mutation in early-onset $\mathrm{BC}$ patients with no family history of the disease. In cohort $C, 3$ recurrent LGRs were reported. The LGR exon 9-12del had a frequency of 6.9\%, making it one of the most frequent BRCA mutations described in the Mexican population.

Three studies were available for Peru. Two studies with cohorts unselected for family history of BC reported 12 different mutations (9 in BRCA1 and 3 in BRCA2). The mutations c68_69delAG, c.1961_1962delA and
c.2808_2811delACAA were recurrent, and 2 LGRs were also detected (Table 2) $[52,53]$. The third publication tested for LGRs in 16 hereditary BC patients but did not test for pathogenic point mutations. The authors detected only one LGR, in BRCA1 (exon 7 amplification) [54].

In Uruguay, only one study described $B R C A$ mutations, in a cohort of 53 patients with heredity BC. Seven mutations were detected (2 in BRCA1 and 5 in $B R C A 2$ ), and no LGR testing was performed [55].

In Venezuela, only one study reported $B R C A$ mutations, again in patients with hereditary $\mathrm{BC}(\mathrm{n}=51)$. The authors described 6 different mutations ( 3 in $B R C A 1$ and 3 in $B R C A 2$ ). No recurrent mutations were reported, and no LGR testing was performed [56].

Table 4 shows $B R C A 1 / 2$ mutations common in more than one Central or South American country, including a total of 21 mutations (14 in BRCA1 and 7 in BRCA2). The most common mutations were found in exons $2,5,11,13,18$ and 20 in $B R C A 1$ and in exons 3 and 11 in $B R C A 2$. Seven mutations were present in 3 or more countries: c.68_69delAG, c.211A>G, c.3331_3334delCAAG and c.5123C $>\mathrm{G}$ in BRCA1 and c.145G $>\mathrm{T}$, c.2808_2811delACAA and c.5946delT in BRCA2. The c.68_69delAG mutation, also known as 185delAG (BRCA1 exon 2), was described in Argentina, Brazil, Chile, Mexico and Peru and was reported as a recurrent mutation in Brazil (0.3\%), Chile (0.6\%) and Peru (2.6\%). The mutation c.211A $>$ G (BRCA1 exon 5) was detected in Argentina, Brazil, Mexico and Peru and was reported as a recurrent mutation in hereditary BC in Argentina (1.17\%). The c.3331_3334delCAAG was present in $\mathrm{BC}$ patients from Brazil, Chile and Colombia and was a recurrent mutation in Chile $(0.9 \%)$ and Colombia (9.4\%). The mutation c.5123C $>\mathrm{A}$ (BRCA1 exon 18) was detected in Argentina (cohort A), Brazil (Cohort A), Colombia (cohort A and C) and Mexico (cohort A, B and $C$ ) and was a recurrent mutation in Colombia (5.7\%) and Mexico (0.5\%). In BRCA2, 6 mutations in exon 11 (c.2808_2811delACAA, c.3264dupT, c.4740_4741insTG, c.535dupA, c.5946delT and c.6024dupG) and one in exon 3 (c.145G $>$ T) were detected in more than one country; c.2808_2811delACAA was a recurrent mutation in Argentina (0.64\%), Colombia (3.8\%) and Peru (0.75\%), and c.145G $>\mathrm{T}$ was a recurrent mutation in Chile (2.6\%).

\section{Other BC susceptibility mutations in Central and South American countries}

There is a consensus that BC risk is attributable to susceptibility alleles in many different genes. In patients negative for $B R C A 1 / 2$ mutations, inherited variations in other genes explain up to $20 \%$ of familial BC [8]. However, $51 \%$ of breast cancer families do not show mutations in $B R C A 1 / 2$ or other known susceptibility genes and 
are therefore classified as BRCAX families. These families may carry a mutation in a moderate-penetrance $\mathrm{BC}$ gene yet to be identified. Alternatively, a truly polygenic model may underlie these cases, with susceptibility conferred by the collective actions of several low-penetrance loci [57-60]. We carried out a literature review of reports on pathogenic mutations or variants in other susceptibility genes in Central and South American countries and found 19 publications between January 2002 and February 2017 in 5 Central or South American countries: Brazil, Chile, Ecuador, Mexico and Peru (Fig. 1). Pathogenic mutations or variants that increase $\mathrm{BC}$ risk were reported in the following genes or genomic regions: $A T M, B A R D 1$, CHECK2, FGFR2, GSTM1, MAP3K1, MTHFR, PALB2, RAD51, TOX3, TP53, XRCC1 and 2q35.

$A T M$ is frequently implicated in hereditary $\mathrm{BC}$ as a low-penetrance susceptibility gene. The ATM kinase has an essential role maintaining genomic integrity, as a key activator of cellular responses to DNA double-strand breaks [61]. In Chile and Mexico, association studies were performed to evaluate the relationship between common ATM variants and familial BC [62,63]. The same variants were studied in both countries: IVS24-9delT and
IVS38-8T $>$ C. Both reports concluded that these variants are associated with increased risk of $\mathrm{BC}$ (Table 5). In Chile, the authors studied the variant $5557 \mathrm{G}>\mathrm{A}$, which was also found to increase BC risk [62].

Germline and somatic mutations in the BARD1 gene are reportedly associated with susceptibility to a subset of breast and ovarian cancers [64]. BARD1 participates in important cellular processes such as DNA repair, RNA processing, transcription, cell cycle regulation and apoptosis [65]. Studies on BARD1 were performed in Chile and Peru (Table 5) [53, 66]. Gonzalez-Hormazabal et al. [66] reported that in Chilean women negative for BRCA1/2 mutations, BARD1 Cys557Ser was associated with increased risk of BC. In Peru, one pathogenic mutation (c.334C $>\mathrm{T}$ ) was reported in one of the triple-negative BC patients studied (0.95\%).

CHEK2 is a gene involved in DNA damage and replication checkpoint responses and has been suggested as a $\mathrm{BC}$ susceptibility gene. The CHEK2 $1100 \mathrm{delC}$ variant, which is associated with increased $\mathrm{BC}$ susceptibility among familial $\mathrm{BC}$ cases not attributable to mutations in BRCA1/2 [67], was studied in Brazilian $(\mathrm{n}=120)$ [31] and Chilean $(\mathrm{n}=196)$ patients with hereditary BC [67].

Table 3 Mutations present in more than one cohort

\begin{tabular}{|c|c|c|c|c|c|}
\hline Country & Mutation & Exon & Hereditary BC & Early-onset BC & Unselected BC \\
\hline \multicolumn{6}{|l|}{ BRCA1 } \\
\hline Brazil & c.5266dupC & 20 & $\boldsymbol{V}^{\mathrm{a}}$ & $\boldsymbol{V}^{\mathrm{a}}$ & $\boldsymbol{\checkmark}^{a}$ \\
\hline Brazil & c. $560+2 \mathrm{~T}>\mathrm{A}$ & 7 & $\checkmark$ & $\checkmark$ & \\
\hline Brazil & c.3331_3334delCAAG & 11 & $\checkmark$ & $\checkmark$ & \\
\hline Brazil & $c .5251 C>T$ & 20 & $\checkmark$ & $\checkmark$ & \\
\hline Colombia & c.3331_3334delCAAG & 11 & $\boldsymbol{V}^{a}$ & & $\boldsymbol{V}^{a}$ \\
\hline Colombia & $C .5123 C>A$ & 18 & $\boldsymbol{V}^{a}$ & & $\boldsymbol{V}^{a}$ \\
\hline Mexico & c.548?_4185?del & 9_12 & & $\checkmark$ & $\checkmark$ \\
\hline Mexico & c.4065_4068delTCAA & 11 & $\checkmark$ & & $\checkmark$ \\
\hline Mexico & c.2296-2297delAG & 11 & & $\checkmark$ & $\checkmark$ \\
\hline Mexico & c.2433delC & 11 & $\checkmark$ & $\checkmark$ & $\checkmark$ \\
\hline Mexico & c. $3598 C>T$ & 11 & & $\checkmark$ & $\checkmark$ \\
\hline Mexico & $c .4327 C>T$ & 13 & & $\checkmark$ & $\checkmark$ \\
\hline Mexico & $c .5123 C>A$ & 18 & $\checkmark$ & $\checkmark$ & $\checkmark$ \\
\hline Mexico & c. $211 A>G$ & 5 & $\checkmark$ & & $\checkmark$ \\
\hline Mexico & c.3759_3760delTA & 11 & $\checkmark$ & & $\checkmark$ \\
\hline \multicolumn{6}{|l|}{ BRCA2 } \\
\hline Brazil & c.2808_2811delACAA & 11 & $\checkmark$ & $\checkmark$ & \\
\hline Colombia & c.2808_2811delACAA & 11 & $\boldsymbol{V}^{a}$ & & $\boldsymbol{V}^{a}$ \\
\hline Mexico & c.2808_2811delACAA & 11 & $\checkmark$ & & $\checkmark$ \\
\hline Mexico & c.1796-1800delTTTAT & 10 & & $\checkmark$ & $\boldsymbol{V}^{a}$ \\
\hline Mexico & $c .4111 C>T$ & 11 & & $\checkmark$ & $\checkmark$ \\
\hline
\end{tabular}

$B C$ breast cancer

$\checkmark=$ Mutation present

a Recurrent mutation 
Only one of the Brazilian patients carried this mutation $(0.83 \%)$, and it was not present is any of the Chilean cases $(\mathrm{n}=196)$. Therefore, this variant is not a common mutation in these two populations (Table 5).

Glutathione S-transferases (GSTs) play an important role in carcinogen detoxification and metabolism of various bioactive compounds [68]. The GST family is composed of six classes of isoenzymes, including GSTM1 [69]. The GSTM1 gene is polymorphic in humans and has three known alleles: GSTM1*A, GSTM1*B and GSTM1O (null), which is the most common variant. The null variant results in undetectable expression of the gene product [70], leading to excessive accumulation of reactive oxygen species and consequently higher susceptibility to carcinogenic events due to DNA damage [71]. Three studies in Mexican and Brazilian populations evaluated the association between the null genotype and BC risk. Two reports concluded that GSTM1O is associated with $\mathrm{BC}$ risk in patients from northeastern Mexico [72] and Guadalajara [69]. In Brazil, a study by Possuelo et al. [73] also reported an association between the null GSTM1 genotype and $\mathrm{BC}$ risk.

The MTHFR enzyme, encoded by the MTHFR gene, is responsible for catalyzing the irreversible conversion of 5,-0-methylenetetrahydrofolate to 5-methylenetetrahydrofolate. The latter molecule is involved in DNA methylation, an important mechanism in regulation of gene expression. Alterations in DNA methylation due to MTHFR polymorphisms may be associated with the development of cancer [74-76]. Association studies on MTHR C677T polymorphisms and BC risk were performed in Brazil [77] and Ecuador [78] (Table 5). In both reports, the authors found a significant association between this SNP and BC risk.

$R A D 51$ is a gene that plays a key role in repairing DNA double-strand breaks through homologous DNA recombination, forming complexes with other proteins involved in DNA repair such as $B R C A 2[79,80]$. Variants or pathogenic mutations in this gene were studied in Chile [81] and Peru [53]. In Chile, no mutations were detected in the exon or splice-boundaries regions of the RAD51 gene. The same study also evaluated the RAD51 5'UTR variant $135 \mathrm{G}>\mathrm{C}$, which is associated with an increased risk of familial BC in BRCA1/2-negative women and early-onset $\mathrm{BC}$ (age $<50$ years at diagnosis). In Peru, the pathogenic mutation c.694C $>\mathrm{T}$ was detected in triple-negative $\mathrm{BC}$ patients $(n=105)$, with a frequency of $0.95 \%$ (Table 5 ).

Mutations in the TP53 tumor suppressor gene also play a significant role in cancer risk, as impaired p53 function may contribute to the multistep process of carcinogenesis [82]. The p53 protein is important in cell-cycle regulation and maintenance of genome stability. The most notable property of p53 is its action as a transcription factor [83]. We found three articles that studied variations in TP53, all in Brazilian populations [31, 84, 85]. These articles studied the c.1010G >A (p.R337H) mutation, which occurs at a high frequency in southern and southeastern Brazil [86-90]. Silva et al. [31] reported a frequency of $2.5 \%$ for this variant and suggested that all BRCA-negative female $\mathrm{BC}$ patients with clinical criteria for hereditary breast-ovarian cancer should be tested for the c.1010G>A variant. Giacomazzi et al. [84] reported that the prevalence of $\mathrm{p} . \mathrm{R} 337 \mathrm{H}$ was higher in women diagnosed with $\mathrm{BC}$ at or before 45 years of age (12.1\%) than in those diagnosed at 55 or older $(5.1 \%)$. An article by Andrade et al. [85] suggested that screening for the germline TP53 p.R337H mutation should be recommended for young females with no family history of cancers associated with Li-Fraumeni syndrome. The three authors agree that inheritance of the $\mathrm{c} .1010 \mathrm{G}>\mathrm{A}$ variant may significantly contribute to the high incidence of $\mathrm{BC}$ in Brazil.

The $X R C C 1$ gene encodes a protein involved in DNA base excision repair. Therefore, mutations or polymorphisms in this gene may be involved in the genetic etiology of $\mathrm{BC}$. The only study on the association between the XRCC1 gene and $\mathrm{BC}$ risk was performed in a Mexican population [91]. Macias-Gomez et al. [91] studied Arg1945Trip and Ag399Gln, reporting a significant association between $\mathrm{BC}$ risk and the 399Gln polymorphism but no significant association with the Arg194Trip polymorphism.

Variations in the FGFR2 gene were studied in Chile [92] and Mexico [93]. The genes or genomic regions in MAP3K, TOX3, PALB2, $2 q 35$ and $8 q 24$ were studied only in Chile (Table 5) [92, 94, 95].

Fibroblast Growth Factor Receptor 2 (FGFR2) and mitogen-activated protein kinase-kinase-kinase 1 (MAP3K1) have been proposed as low-penetrance BC susceptibility genes [57]. A study by Jara et al. [92] used a case-control design to evaluate the association of BC with the FGFR2 SNPs rs2981582, rs2420946 and rs121648 and the MAP3K1 SNP rs889312 in BRCA1/2negative Chilean BC cases. All of the SNPs studied were significantly associated with increased $\mathrm{BC}$ risk in familial $\mathrm{BC}$ and non-familial early-onset $\mathrm{BC}$, in a dose-dependent manner. In Mexico, a study by Murillo-Zamora et al. [93] reported that rs2981582 was associated with BC risk $(\mathrm{p}=0.007)($ Table 5$)$.

In the TOX3/LOG643714 (also known as TNRC9) locus, several SNPs associated with BC risk were identified. Among these, rs380362 is the most strongly correlated with disease [57]. The SNPs rs13387042 (2q35) and rs13281615 (8q24), located in non-coding regions, 
Table 4 Common BRCA $1 / 2$ mutation found in multiple Central and South American countries

\begin{tabular}{|c|c|c|c|c|c|c|c|c|}
\hline \multicolumn{6}{|c|}{ Mutation in BRCA 1} & \multicolumn{3}{|c|}{ Frequency of recurrent mutation (\%) } \\
\hline Exon & Mutation & Country & Hereditary & Early-onset BC & Unselected BC & Hereditary BC & Early-onset BC & $\begin{array}{l}\text { Unselected } \\
\text { BC }\end{array}$ \\
\hline \multirow[t]{5}{*}{2} & c.68_69delAG & Argentina & $\checkmark$ & & & & & \\
\hline & & Brazil & $\checkmark$ & & & $0.33 \%$ & & \\
\hline & & Chile & $\checkmark$ & & & $0.6 \%$ & & \\
\hline & & Mexico & & & $\checkmark$ & & & \\
\hline & & Peru & & & $\checkmark$ & & & $2.6 \%$ \\
\hline \multirow[t]{3}{*}{5} & c. $181 \mathrm{~T}>\mathrm{G}$ & Argentina & $\checkmark$ & & & $0.64 \%$ & & \\
\hline & & Brazil & & $\checkmark$ & & & & \\
\hline & & Chile & $\checkmark$ & & & & & \\
\hline \multirow[t]{4}{*}{5} & c. $211 \mathrm{~A}>\mathrm{G}$ & Argentina & $\checkmark$ & & & $1.17 \%$ & & \\
\hline & & Brazil & $\checkmark$ & & & & & \\
\hline & & Mexico & $\checkmark$ & & $\checkmark$ & & & \\
\hline & & Peru & & & $\checkmark$ & & & \\
\hline \multirow[t]{2}{*}{11} & c. 798_799delTT & Argentina & $\checkmark$ & & & & & \\
\hline & & Mexico & & & $\checkmark$ & & & \\
\hline \multirow[t]{2}{*}{11} & c.815_824dupAGCCATGTGG & Mexico & & & $\checkmark$ & & & \\
\hline & & Peru & & & $\checkmark$ & & & \\
\hline \multirow[t]{2}{*}{11} & c. $2568 \mathrm{~T}>\mathrm{G}$ & Argentina & $\checkmark$ & & & & & \\
\hline & & Uruguay & $\checkmark$ & & & & & \\
\hline \multirow[t]{2}{*}{11} & c.3228_3229delAG & Argentina & $\checkmark$ & & & & & \\
\hline & & Brazil & & & $\checkmark$ & & & \\
\hline \multirow[t]{3}{*}{11} & c. 3331_3334delCAAG & Brazil & $\checkmark$ & & & & & \\
\hline & & Chile & $\checkmark$ & & & $0.9 \%$ & & \\
\hline & & Colombia & $\checkmark$ & & $\checkmark$ & $9.4 \%$ & & $1.6 \% / 11.4 \%^{\mathrm{a}}$ \\
\hline \multirow[t]{2}{*}{11} & c. 3858_3861delTGAG & Mexico & $\checkmark$ & & $\checkmark$ & & & \\
\hline & & Peru & & & $\checkmark$ & & & \\
\hline \multirow[t]{2}{*}{11} & c. 3858_3861delTGAG & Chile & $\checkmark$ & & & & & \\
\hline & & Mexico & & & $\checkmark$ & & & \\
\hline \multirow[t]{2}{*}{11} & c. 4065_4068delTCAA & Mexico & & & $\checkmark$ & & & \\
\hline & & Peru & & & $\checkmark$ & & & \\
\hline \multirow[t]{2}{*}{13} & $c .4327>T$ & Argentina & $\checkmark$ & & & & & \\
\hline & & Mexico & & $\checkmark$ & $\checkmark$ & & & $0.25 \%$ \\
\hline \multirow[t]{4}{*}{18} & c. $5123 C>A$ & Argentina & $\checkmark$ & & & & & \\
\hline & & Brazil & $\checkmark$ & & & & & \\
\hline & & Colombia & $\checkmark$ & & $\checkmark$ & $5.7 \%$ & & $1.3 \%$ \\
\hline & & Mexico & $\checkmark$ & $\checkmark$ & $\checkmark$ & & & $0.5 \%$ \\
\hline \multirow[t]{2}{*}{20} & c.5266up C & Argentina & $\checkmark$ & & & & & \\
\hline & & Brazil & $\checkmark$ & $\checkmark$ & $\checkmark$ & $2.5 \% / 0.65 \% / 5 \%^{\mathrm{a}}$ & $3.7 \%$ & $1.2 \%$ \\
\hline \multicolumn{9}{|c|}{ Mutation in BRCA 2} \\
\hline \multirow[t]{3}{*}{3} & c. $145 G>T$ & Argentina & $\checkmark$ & & & & & \\
\hline & & Chile & $\checkmark$ & & & $3.7 \%$ & & \\
\hline & & Mexico & $\checkmark$ & & & & & \\
\hline \multirow[t]{6}{*}{11} & c.2808_2811 delACAA & Argentina & $\checkmark$ & & & $0.64 \%$ & & \\
\hline & & Brazil & $\checkmark$ & $\checkmark$ & & & & \\
\hline & & Colombia & $\checkmark$ & & $\checkmark$ & $3.8 \%$ & & $1.3 \%$ \\
\hline & & Mexico & $\checkmark$ & & $\checkmark$ & & & \\
\hline & & Peru & & & $\checkmark$ & & & $0.75 \%$ \\
\hline & & Venezuela & $\checkmark$ & & & & & \\
\hline
\end{tabular}


Table 4 continued

\begin{tabular}{|c|c|c|c|c|c|c|c|c|}
\hline \multicolumn{6}{|c|}{ Mutation in BRCA 1} & \multicolumn{3}{|c|}{ Frequency of recurrent mutation (\%) } \\
\hline Exon & Mutation & Country & Hereditary & Early-onset BC & Unselected BC & Hereditary BC & Early-onset BC & $\begin{array}{l}\text { Unselected } \\
\text { BC }\end{array}$ \\
\hline \multirow[t]{2}{*}{11} & c.3264d up T & Argentina & $\checkmark$ & & & & & \\
\hline & & Mexico & $\checkmark$ & & & & & \\
\hline \multirow[t]{2}{*}{11} & c.4740_4741insTG & Argentina & $\checkmark$ & & & & & \\
\hline & & Chile & $\checkmark$ & & & $0.6 \%$ & & \\
\hline \multirow[t]{2}{*}{11} & c.5351dup A & Argentina & $\checkmark$ & & & & & \\
\hline & & Uruguay & $\checkmark$ & & & & & \\
\hline \multirow[t]{4}{*}{11} & c. 5946delT & Argentina & $\checkmark$ & & & & & \\
\hline & & Brazil & & & $\checkmark$ & & & \\
\hline & & Chile & $\checkmark$ & & & & & \\
\hline & & Costa Rica & $\checkmark$ & & & & & \\
\hline \multirow[t]{3}{*}{11} & c.6024dup G & Argentina & $\checkmark$ & & & & & \\
\hline & & Colombia & & & $\checkmark$ & & & \\
\hline & & Mexico & & & $\checkmark$ & & & \\
\hline
\end{tabular}

$B C$ breast cancer

$\checkmark=$ Mutation present

${ }^{a}$ Values obtained in different publication

were also associated with $\mathrm{BC}$ risk $[57,60]$. In a Chilean population, Elematore et al. [94] evaluated the association between rs380362 (TOX3), rs13387042 (2q35) and rs13281615 (8q24) and BC risk in 344 BRCA1/2-negative BC cases and 801 controls. Two SNPs, rs380362 and rs13387042, were significantly associated with increased $\mathrm{BC}$ risk in familial $\mathrm{BC}$ and non-familial early-onset $\mathrm{BC}$. The risk of $\mathrm{BC}$ increased in a dose-dependent manner with the number of risk alleles ( $\mathrm{p}$-trend $<0.0001$ and 0.0091 , respectively). Other studies reported an additive effect of the rs380362 and 2q35 rs1387042 alleles on $\mathrm{BC}$ risk. There was no association between rs13281615 (8q24) and BC risk (Table 5).

The PALB2 (partner and localizer of BRCA2) protein interacts with BRCA2, stabilizing the intracellular accumulation of the BRCA2 protein at sites of DNA damage [96]. PALB2 is also recruited by BRCA1 in response to DNA damage and serves as a linker between BRCA1 and BRCA2 and is necessary for BRCA2-mediated homologous-recombination repair [97, 98]. Thus, BRCA1, BRCA2 and PALB2 are key BC susceptibility genes that work together in the same DNA damage response pathway $[99,100]$. Leyton et al. [95] studied 100 BRCA1/2-negative Chilean cases with familial $\mathrm{BC}$, identifying 3 PALB2 variants. Using a casecontrol design, the authors evaluated the association of the identified variants with $B C$ risk. Two of the variants, PALB2 c.1676A $>$ G(rs152451A $>$ G) and c. $2993 \mathrm{C}>\mathrm{T}$ $($ rs $45551636 \mathrm{C}>\mathrm{T})$, were significantly associated with increased $\mathrm{BC}$ risk only in cases with a strong family history of BC (Table 5).
The relationship of $B R C A 1 / 2$ mutations and other $B C$ susceptibility variants to the demographic composition of Central and South American countries

Genetic factors play an important role in the development of BC. The most widely-accepted model of BC oncogenesis, known as the polygenic model, attributes $B C$ susceptibility to a small number ethnicity-specific mutations in high-penetrance genes (BRCA1, BRCA2 and TP53) and a much larger number of variants in moderate- or low-penetrance genes [7, 101], as well as interactions among these genetic variants and exposure to environmental factors [102]. Both BRCA1 and BRCA2 confer susceptibility to breast and ovarian cancer. About $5-7 \%$ of all $\mathrm{BC}$ diagnosed are associated with germline mutations in BRCA1 and BRCA2 [8, 15], and an even larger proportion of familial $\mathrm{BC}$ cases are associated with $B R C A 1$ and $B R C A 2$ variations; collectively, germline mutations in the two major susceptibility genes $B R C A 1$ and $B R C A 2$ account for $\sim 20 \%$ of familial BC cases $[8$, 103]. The spectrum of mutations in BRCA1 and BRCA2 genes and other susceptibility alleles varies considerably by ethnic group and geographic region.

South America has a complex demographic history shaped by multiple migration and admixture events in pre- and post-colonial times [104], including settlement by Native Americans, European colonization and the African slave trade [104]. Moreover, the continental ancestry of the admixed populations in South America is not homogenous. For example, the Argentine population is a mixture of European (0.673), Native American (0.277), West African (0.036) and East Asian (0.014) 


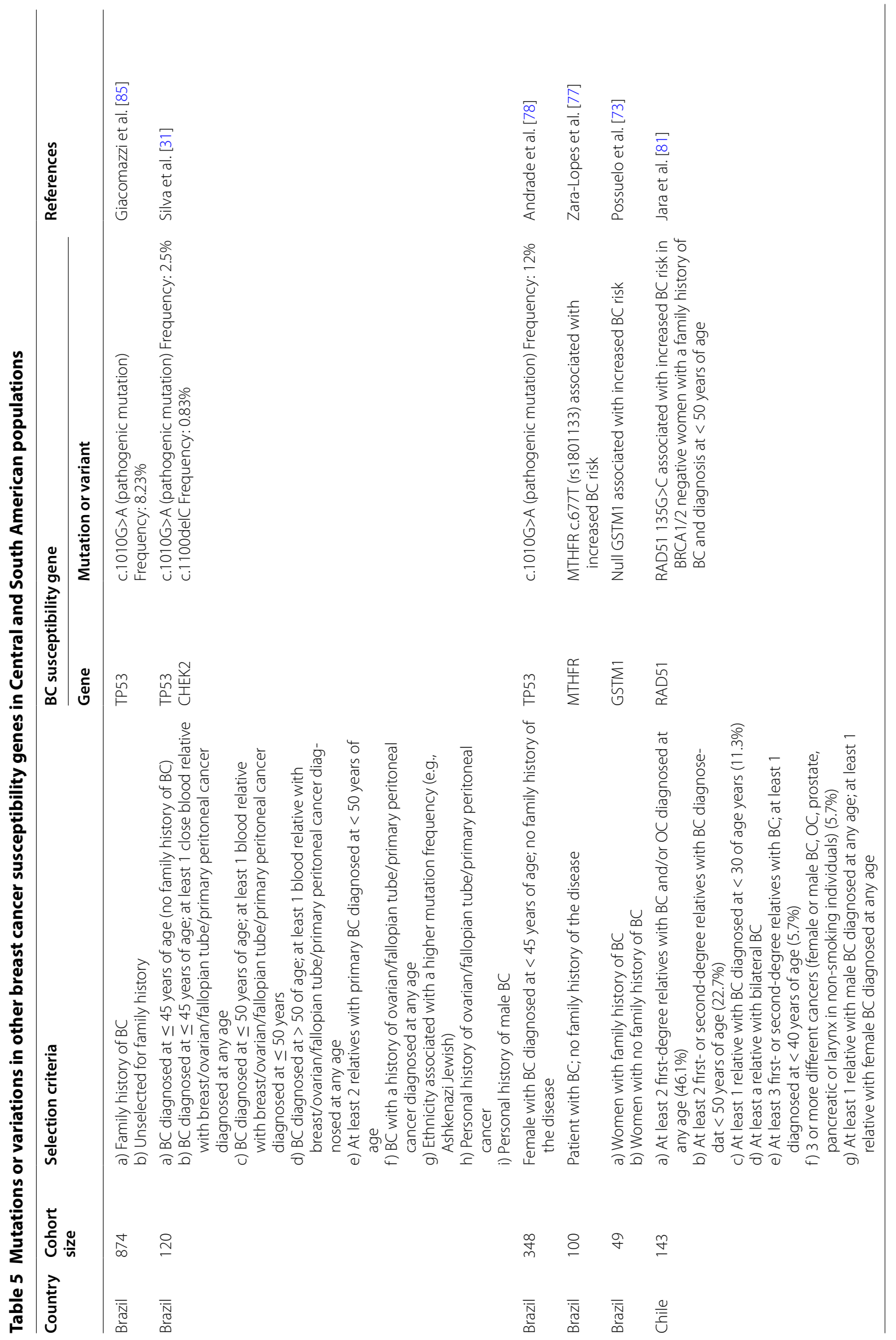




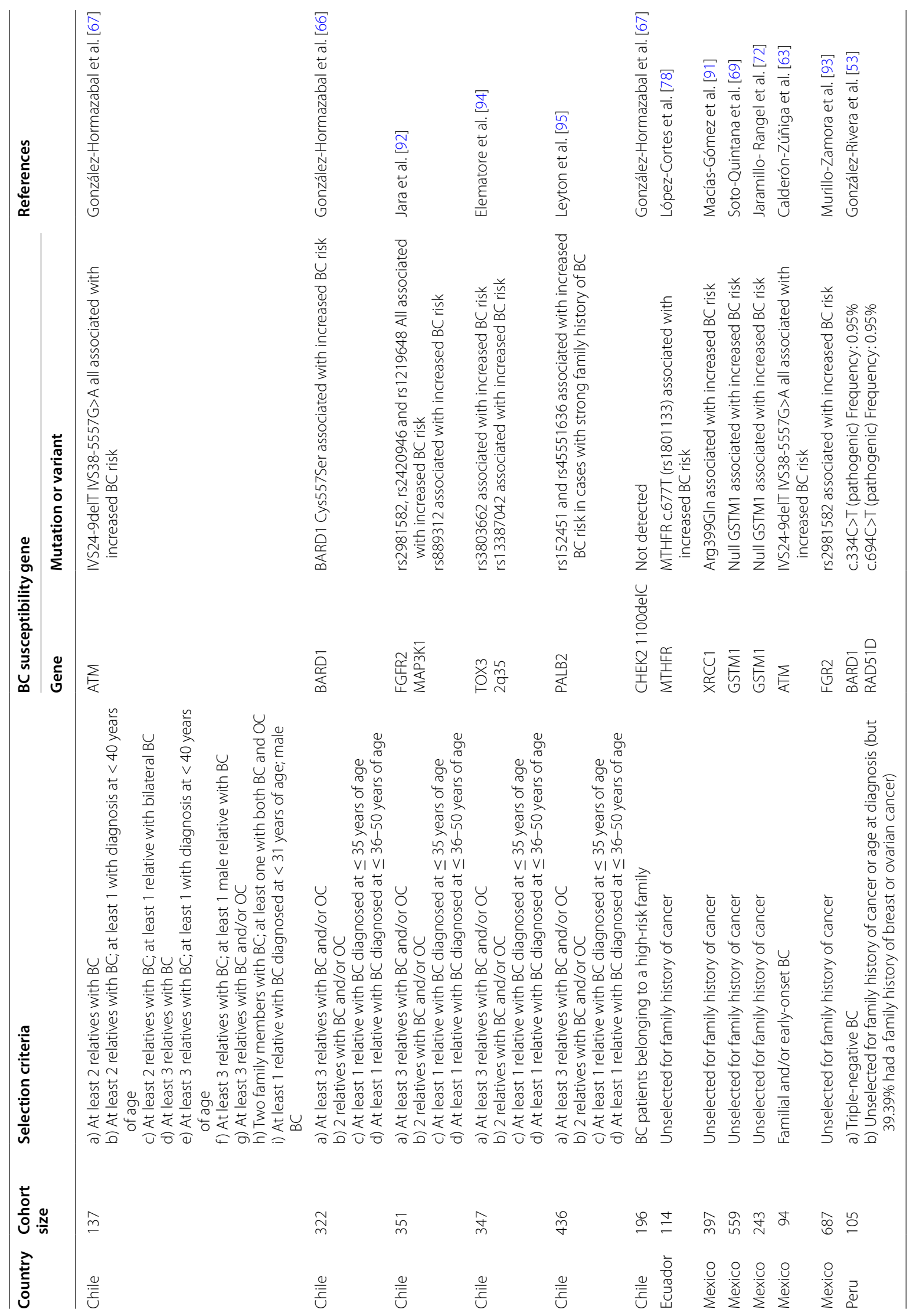


components, while the proportions in the Peruvian population are European (0.26), Native American (0.683), West African (0.032) and East Asian (0.025) [104]. Uruguay is unique among South American countries in that it has almost no communities of Native American or African descent [105]. Therefore, South American countries should not be analyzed as a monolithic group without regard for specific regional genetic ancestry, as the ethnic differences between South American populations suggests that medically-relevant genetic variations may differ according to population and region.

Mexico and Costa Rica were the only Central American populations with data on BRCA mutations. Central America was included in this review as it was also colonized by Spaniards. The Costa Rica population is a mixture of European (0.61), Native American (0.31) and African (0.06) components, with variations by region [106]. For example, a recent study on the genetic and population substructure in Guanacaste, Costa Rica, which is heavily admixed, reported a mixture of predominantly European (0.425), Native American (0.383) and African (0.152) ancestry, although the authors could not exclude an Asian component (0.04) [107].

The Mexican population also harbors great ethnic diversity [108] as confirmed by numerous studies on the admixture in Mexico. Amerindian ancestry is the largest component (0.51-0.56) in the general population, followed by European (0.40-0.45), while the African component is small $(0.02-0.05)$. When analyzed by region, however, there is significant variation. For example, European is the largest component in the north (at 0.5 in Chihuahua, 0.62 in Sonora and 0.55 in Nueva Leon) [105].

An overview of the literature indicates a marked Amerindian influence in Mexican and Peruvian populations, while European ancestry is more prevalent in Costa Rica, Argentina and Uruguay. The proportions of European, Amerindian and African components are roughly equal in Venezuela. In Colombia and Brazil, there is significant interpopulation variability. The ethnic distribution in Brazil follows a geographical pattern, with the European influence more prevalent in the southeast and south, African in northeast and Amerindian in the north. In Chile, the Amerindian and European components are 0.6 and 0.4 , respectively [105].

\section{Genetic testing for breast cancer}

Genetic testing for BRCA1 and BRCA2 mutations may provide significant public health benefits for cancer patients and high-risk individuals, who could be offered targeted treatment and prevention strategies [109]. The feasibility of providing widespread genetic screening for $B R C A 1 / 2$ mutations in Central and South America depends on knowledge of mutations present in these regions, given the varied ethnic composition of the populations. To develop a test that might be useful throughout the region and therefore sufficiently cost-effective, it is first necessary to determine which $B R C A 1 / 2$ mutations are common in multiple countries. Public insurance coverage for genetic testing is also crucial. Finally, it is important to identify pathogenic mutations or variants in other moderate- or low-penetrance susceptibility genes that increase $\mathrm{BC}$ risk, as the use of panel testing is growing more common.

\section{Conclusions}

The BRCA1/2 gene mutation spectrum varies widely throughout different Central and South American populations, likely due to the patterns of ethnic diversity in these countries. These complex ethnic patterns are associated with various migration and settlement events. Even populations within a given country are not necessarily homogeneous, and each subgroup may have a distinct ethnic composition and genetic structure. Because the same genetic composition cannot be extrapolated across diverse sub-populations, genetic screening tests for breast cancer in these regions should not be based on a single genetic test with a defined gene variant panel to detect mutational events. This guideline is even more categorical for screening approaches designed to test more than one population in Central and or South American countries.

A significant percentage of high-risk families with hereditary breast cancer are negative for mutations in BRCA1/2 genes. The genetic etiology of $\mathrm{BC}$ in these subjects may be attributable to variations in other moderateor low-penetrance susceptibility alleles and/or variations in specific chromosomal regions. Data on variants in these genes and/or chromosomal regions in Central and South American populations are even scarcer than studies involving high-penetrance alleles. Given the importance of these variants in the etiology of hereditary BC, elucidating the distribution of these mutations and variations is crucial for advancing population studies and screening approaches in high-risk families with a hereditary breast cancer profile.

Appropriate inclusion criteria are also of vital importance when conducting these studies, given the considerable variability observed in the reported studies.

\section{Additional file}

Additional file 1: Table S1. Cohort characteristics and pathogenic BRCA1 and BRCA2 mutations in hereditary breast cancer in Central and South American populations. 


\section{Abbreviations}

BRCA1: breast cancer type 1 susceptibility protein; BRCA2: breast cancer type 2 susceptibility protein; LGRs: large genomic rearrangements; ATM: ataxia telangiectasia mutaded gene; BARD1: BRCA1 associated ring domain 1; CHEK2: Checkpoint kinase 2; GSTs: glutathione S-transferases; MTHFR: methylenetetrahydrofolate reductase; RAD51: BRCA1/BRCA2-containing complex, subunit 5; TP53: phosphoprotein P53; XRCC1: X-ray repair cross-complementing protein 1; FGFR2: fibroblast growth factor receptor 2; MAP3K1: mitogen-activated protein kinase-kinase-kinase 1; TOX3/LOG643714: TOX high mobility group box family member 3; PALB2: partner and localizer of BRCA2.

\section{Authors' contributions}

$\mathrm{LJ}$ conceived the study and wrote the paper. RG, PGH and VC participated to draft the literature and the manuscript. SM and TDM contribute with the tables and figure preparation, study concepts and design, and manuscript editing. All authors read and approved the final manuscript.

\section{Author details}

${ }^{1}$ Human Genetics Program, Institute of Biomedical Sciences (ICBM), School of Medicine, University of Chile, Santiago, Chile. ${ }^{2}$ Center for Genetics and Genomics Faculty of Medicine, Clinica Alemana Universidad del desarrollo, Avenida Las Condes, 12438 Lo Barnechea, Santiago, Chile. ${ }^{3}$ Laboratorio de Genética Molecular Humana, Facultad de Medicina, Instituto de Ciencias Biomédicas (ICBM), Programa de Genética, Universidad de Chile, Independencia 1027, Santiago, Chile.

\section{Competing interests}

The authors declare that they have no competing interests.

\section{Availability of data and materials}

All dataset used and analyzed during this study are included in this published article and its Additional file 1: Table S1.

\section{Consent for publication}

Not applicable.

\section{Ethics approval and consent to participate}

Not applicable.

\section{Funding}

Fondo Nacional de Desarrollo Científico y Tecnológico (FONDECYT), Grant Number 1150117

\section{Publisher's Note}

Springer Nature remains neutral with regard to jurisdictional claims in published maps and institutional affiliations.

Received: 8 August 2017 Accepted: 20 September 2017 Published online: 06 October 2017

\section{References}

1. Parkin DM, Fernandez LM. Use of statistics to assess the global burden of breast cancer. Breast J. 2006;12(Suppl 1):S70-80. doi:10.1111/j.1075-122X.2006.00205.x.

2. Oldenburg RA, Meijers-Heijboer H, Cornelisse CJ, Devilee P. Genetic susceptibility for breast cancer: how many more genes to be found? Crit Rev Oncol Hematol. 2007;63(2):125-49. doi:10.1016/j. critrevonc.2006.12.004.

3. Jemal A, Siegel R, Ward E, Hao Y, Xu J, Thun MJ. Cancer statistics, 2009. CA Cancer J Clin. 2009;59(4):225-49. doi:10.3322/caac.20006.

4. Wooster R, Neuhausen SL, Mangion J, Quirk Y, Ford D, Collins N, et al. Localization of a breast cancer susceptibility gene, BRCA2, to chromosome 13q12-13. Science. 1994;265(5181):2088-90.

5. Tavtigian SV, Simard J, Rommens J, Couch F, Shattuck-Eidens D, Neuhausen $\mathrm{S}$, et al. The complete BRCA2 gene and mutations in chromosome 13q-linked kindreds. Nat Genet. 1996;12(3):333-7. doi:10.1038/ ng0396-333.
6. Anglian Breast Cancer Study Group. Prevalence and penetrance of BRCA1 and BRCA2 mutations in a population-based series of breast cancer cases. Anglian Breast Cancer Study Group. Br J Cancer. 2000;83(10):1301-8. doi:10.1054/bjoc.2000.1407.

7. Stratton MR, Rahman N. The emerging landscape of breast cancer susceptibility. Nat Genet. 2008;40(1):17-22. doi:10.1038/ng.2007.53.

8. Melchor $\mathrm{L}$, Benitez $\mathrm{J}$. The complex genetic landscape of familial breast cancer. Hum Genet. 2013;132(8):845-63. doi:10.1007/ s00439-013-1299-y.

9. Claus EB, Schildkraut JM, Thompson WD, Risch NJ.

The genetic attributable risk of breast and ovarian cancer. Cancer. 1996;77(11):2318-24. doi:10.1002/ (SICI)1097-0142(19960601)77:11<2318:AID-CNCR21>3.0.CO;2-Z.

10. Antoniou A, Pharoah PD, Narod S, Risch HA, Eyfjord JE, Hopper JL, et al. Average risks of breast and ovarian cancer associated with BRCA1 or BRCA2 mutations detected in case Series unselected for family history: a combined analysis of 22 studies. Am J Hum Genet. 2003;72(5):111730. doi:10.1086/375033.

11. Antoniou AC, Cunningham AP, Peto J, Evans DG, Lalloo F, Narod SA, et al. The BOADICEA model of genetic susceptibility to breast and ovarian cancers: updates and extensions. Br J Cancer. 2008;98(8):1457-66. doi:10.1038/sj.bjc.6604305.

12. Begg CB, Haile RW, Borg A, Malone KE, Concannon P, Thomas DC, et al. Variation of breast cancer risk among BRCA1/2 carriers. JAMA. 2008;299(2):194-201. doi:10.1001/jama.2007.55-a.

13. Brohet RM, Velthuizen ME, Hogervorst FB, Meijers-Heijboer HE, Seynaeve C, Collee MJ, et al. Breast and ovarian cancer risks in a large series of clinically ascertained families with a high proportion of BRCA1 and BRCA2 Dutch founder mutations. J Med Genet. 2014;51(2):98-107. doi:10.1136/jmedgenet-2013-101974.

14. Chen S, Iversen ES, Friebel T, Finkelstein D, Weber BL, Eisen A, et al. Characterization of BRCA1 and BRCA2 mutations in a large United States sample. J Clin Oncol Off J Am Soci Clin Oncol. 2006;24(6):863-71. doi:10.1200/JCO.2005.03.6772.

15. Ford D, Easton DF, Stratton M, Narod S, Goldgar D, Devilee P, et al. Genetic heterogeneity and penetrance analysis of the BRCA1 and BRCA2 genes in breast cancer families. The breast cancer linkage consortium. Am J Hum Genet. 1998;62(3):676-89.

16. Gabai-Kapara E, Lahad A, Kaufman B, Friedman E, Segev S, Renbaum P, et al. Population-based screening for breast and ovarian cancer risk due to BRCA1 and BRCA2. Proc Natl Acad Sci USA. 2014;111(39):14205-10. doi:10.1073/pnas.1415979111.

17. Hopper JL, Southey MC, Dite GS, Jolley DJ, Giles GG, McCredie MR, et al. Population-based estimate of the average age-specific cumulative risk of breast cancer for a defined set of protein-truncating mutations in BRCA1 and BRCA2. Australian Breast Cancer Family Study. Cancer Epidemiol Biomark Prev Pub Am Assoc Cancer Res Cosponsored Am Soci Prev Oncol. 1999;8(9):741-7.

18. Milne RL, Osorio A, Cajal TR, Vega A, Llort G, de la Hoya M, et al. The average cumulative risks of breast and ovarian cancer for carriers of mutations in BRCA1 and BRCA2 attending genetic counseling units in Spain. Clin Cancer Res Off J Am Assoc Cancer Res. 2008;14(9):2861-9. doi:10.1158/1078-0432.CCR-07-4436.

19. Evans DG, Shenton A, Woodward E, Lalloo F, Howell A, Maher ER. Penetrance estimates for BRCA1 and BRCA2 based on genetic testing in a Clinical Cancer Genetics service setting: risks of breast/ovarian cancer quoted should reflect the cancer burden in the family. BMC cancer. 2008;8:155. doi:10.1186/1471-2407-8-155.

20. Miki Y, Swensen J, Shattuck-Eidens D, Futreal PA, Harshman K, Tavtigian $\mathrm{S}$, et al. A strong candidate for the breast and ovarian cancer susceptibility gene BRCA1. Science. 1994;266(5182):66-71.

21. Smith P, McGuffog L, Easton DF, Mann GJ, Pupo GM, Newman B, et al. A genome wide linkage search for breast cancer susceptibility genes. Genes Chromosom Cancer. 2006;45(7):646-55. doi:10.1002/ gcc. 20330

22. Mavaddat N, Pharoah PD, Michailidou K, Tyrer J, Brook MN, Bolla MK et al. Prediction of breast cancer risk based on profiling with common genetic variants. J Natl Cancer Inst. 2015;107(5). doi:10.1093/jnci/ djv036.

23. Kenemans $\mathrm{P}$, Verstraeten $\mathrm{RA}$, Verheijen $\mathrm{RH}$. Oncogenic pathways in hereditary and sporadic breast cancer. Maturitas. 2008;61(1-2):141-50. 
24. Metcalfe KA, Snyder C, Seidel J, Hanna D, Lynch HT, Narod S. The use of preventive measures among healthy women who carry a BRCA1 or BRCA2 mutation. Fam Cancer. 2005;4(2):97-103. doi:10.1007/s10689-005-4215-3.

25. Narod SA, Foulkes WD. BRCA1 and BRCA2: 1994 and beyond. Nat Rev Cancer. 2004;4(9):665-76. doi:10.1038/nrc1431.

26. Warner E, Causer PA. MRI surveillance for hereditary breast-cancer risk. Lancet. 2005;365(9473):1747-9. doi:10.1016/S0140-6736(05)66520-8.

27. Weitzel JN, Buys SS, Sherman WH, Daniels A, Ursin G, Daniels JR, et al. Reduced mammographic density with use of a gonadotropin-releasing hormone agonist-based chemoprevention regimen in BRCA1 carriers. Clin Cancer Res Off J Am Assoc Cancer Res. 2007;13(2 Pt 1):654-8. doi:10.1158/1078-0432.CCR-06-1902.

28. Tutt A, Robson M, Garber JE, Domchek SM, Audeh MW, Weitzel JN, et al. Oral poly(ADP-ribose) polymerase inhibitor olaparib in patients with BRCA1 or BRCA2 mutations and advanced breast cancer: a proof-of-concept trial. Lancet. 2010;376(9737):235-44. doi:10.1016/ S0140-6736(10)60892-6.

29. Solano AR, Cardoso FC, Romano V, Perazzo F, Bas C, Recondo G, et al. Spectrum of BRCA1/2 variants in 940 patients from Argentina including novel, deleterious and recurrent germline mutations: impact on healthcare and clinical practice. Oncotarget. 2016;. doi:10.18632/ oncotarget.10814.

30. Ewald IP, Cossio SL, Palmero El, Pinheiro M, Nascimento IL, Machado TM, et al. BRCA1 and BRCA2 rearrangements in Brazilian individuals with hereditary breast and ovarian cancer syndrome. Genet Mol Biol. 2016;39(2):223-31. doi:10.1590/1678-4685-GMB-2014-0350.

31. Silva FC, Lisboa BC, Figueiredo MC, Torrezan GT, Santos EM, Krepischi $A C$, et al. Hereditary breast and ovarian cancer: assessment of point mutations and copy number variations in Brazilian patients. BMC Med Genet. 2014;15:55. doi:10.1186/1471-2350-15-55.

32. Felix GE, Abe-Sandes C, Machado-Lopes TM, Bomfim TF, Guindalini RS, Santos VC, et al. Germline mutations in BRCA1, BRCA2, CHEK2 and TP53 in patients at high-risk for HBOC: characterizing a Northeast Brazilian Population. Hum Gen Var. 2014;1:14012. doi:10.1038/hgv.2014.12.

33. Dufloth RM, Carvalho S, Heinrich JK, Shinzato JY, dos Santos CC, Zeferino LC, et al. Analysis of BRCA1 and BRCA2 mutations in Brazilian breast cancer patients with positive family history. Sao Paulo Med J Rev Paul Med. 2005;123(4):192-7.

34. Esteves VF, Thuler LC, Amendola LC, Koifman RJ, Koifman S, Frankel PP, et al. Prevalence of BRCA1 and BRCA2 gene mutations in families with medium and high risk of breast and ovarian cancer in Brazil. Braz J Med Biol Res. 2009;42(5):453-7.

35. Ewald IP, Izetti P, Vargas FR, Moreira MA, Moreira AS, Moreira-Filho CA, et al. Prevalence of the BRCA1 founder mutation c.5266dupin Brazilian individuals at-risk for the hereditary breast and ovarian cancer syndrome. Hered Cancer Clin Pract. 2011;9:12. doi:10.1186/1897-4287-9-12.

36. Carraro DM, Koike Folgueira MA, Garcia Lisboa BC, Ribeiro Olivieri EH, Vitorino Krepischi AC, de Carvalho AF, et al. Comprehensive analysis of BRCA1, BRCA2 and TP53 germline mutation and tumor characterization: a portrait of early-onset breast cancer in Brazil. PLoS ONE. 2013;8(3):e57581. doi:10.1371/journal.pone.0057581.

37. Gomes MC, Costa MM, Borojevic R, Monteiro AN, Vieira R, Koifman $\mathrm{S}$, et al. Prevalence of BRCA1 and BRCA2 mutations in breast cancer patients from Brazil. Breast Cancer Res Treat. 2007;103(3):349-53. doi:10.1007/s10549-006-9378-6.

38. Gonzalez-Hormazabal P, Gutierrez-Enriquez S, Gaete D, Reyes JM, Peralta O, Waugh E, et al. Spectrum of BRCA1/2 point mutations and genomic rearrangements in high-risk breast/ovarian cancer Chilean families. Breast Cancer Res Treat. 2011;126(3):705-16. doi:10.1007/ s10549-010-1170-y.

39. Gallardo M, Silva A, Rubio L, Alvarez C, Torrealba C, Salinas M, et al. Incidence of BRCA1 and BRCA2 mutations in 54 Chilean families with breast/ovarian cancer, genotype-phenotype correlations. Breast Cancer Res Treat. 2006;95(1):81-7. doi:10.1007/s10549-005-9047-1.

40. Sanchez A, Faundez P, Carvallo P. Genomic rearrangements of the BRCA1 gene in Chilean breast cancer families: an MLPA analysis. Breast Cancer Res Treat. 2011;128(3):845-53. doi:10.1007/s10549-011-1382-9.

41. Torres D, Rashid MU, Gil F, Umana A, Ramelli G, Robledo JF, et al. High proportion of BRCA1/2 founder mutations in hispanic breast/ ovarian cancer families from Colombia. Breast Cancer Res Treat. 2007;103(2):225-32. doi:10.1007/s10549-006-9370-1.
42. Rodriguez AO, Llacuachaqui M, Pardo GG, Royer R, Larson G, Weitzel JN, et al. BRCA1 and BRCA2 mutations among ovarian cancer patients from Colombia. Gynecol Oncol. 2012;124(2):236-43. doi:10.1016/j. ygyno.2011.10.027.

43. Hernandez JE, Llacuachaqui M, Palacio GV, Figueroa JD, Madrid J, Lema $M$, et al. Prevalence of BRCA1 and BRCA2 mutations in unselected breast cancer patients from medellin, Colombia. Hered Cancer Clin Pract. 2014;12(1):11. doi:10.1186/1897-4287-12-11.

44. Torres D, Umana A, Robledo JF, Caicedo JJ, Quintero E, Orozco A, et al. Estudio de factores genéticos para cáncer de mama en Colombia. Univ Med Bogotá. 2009;50(3):297-301.

45. Gutierrez Espeleta GA, Llacuachaqui M, Garcia-Jimenez L, Aguilar Herrera M, Loaiciga Vega K, Ortiz A, et al. BRCA1 and BRCA2 mutations among familial breast cancer patients from Costa Rica. Clin Genet. 2012;82(5):484-8. doi:10.1111/j.1399-0004.2011.01774.x.

46. Vaca-Paniagua F, Alvarez-Gomez RM, Fragoso-Ontiveros V, Vidal-Millan S, Herrera LA, Cantu D, et al. Full-exon pyrosequencing screening of BRCA germline mutations in Mexican women with inherited breast and ovarian cancer. PLoS ONE. 2012;7(5):e37432. doi:10.1371/journal. pone.0037432.

47. Nahleh Z, Otoukesh S, Dwivedi AK, Mallawaarachchi I, Sanchez L, Saldivar JS, et al. Clinical and pathological characteristics of Hispanic BRCA-associated breast cancers in the American-Mexican border city of El Paso, TX. Am J Cancer Res. 2015;5(1):466-71.

48. Ruiz-Flores P, Sinilnikova OM, Badzioch M, Calderon-Garciduenas AL, Chopin S, Fabrice O, et al. BRCA1 and BRCA2 mutation analysis of early-onset and familial breast cancer cases in Mexico. Hum Mutat. 2002;20(6):474-5. doi:10.1002/humu.9084.

49. Calderon-Garciduenas AL, Ruiz-Flores P, Cerda-Flores RM, BarreraSaldana HA. Clinical follow up of mexican women with early onset of breast cancer and mutations in the BRCA1 and BRCA2 genes. Salud Publica Mex. 2005;47(2): 110-5.

50. Torres-Mejia G, Royer R, Llacuachaqui M, Akbari MR, Giuliano AR, Martinez-Matsushita $L$, et al. Recurrent BRCA1 and BRCA2 mutations in Mexican women with breast cancer. Cancer Epidemiol Biomark Prev Pub Am Assoc Cancer Res Cosponsored Am Soci Prev Oncol. 2015;24(3):498-505. doi:10.1158/1055-9965.EPI-13-0980.

51. Villarreal-Garza C, Alvarez-Gomez RM, Perez-Plasencia C, Herrera $L A$, Herzog J, Castillo D, et al. Significant clinical impact of recurrent BRCA1 and BRCA2 mutations in Mexico. Cancer. 2015;121(3):372-8. doi:10.1002/cncr.29058.

52. Abugattas J, Llacuachaqui M, Allende YS, Velasquez AA, Velarde R, Cotrina J, et al. Prevalence of BRCA1 and BRCA2 mutations in unselected breast cancer patients from Peru. Clin Genet. 2015;88(4):371-5. doi:10.1111/cge.12505.

53. Gonzalez-Rivera M, Lobo M, Lopez-Tarruella S, Jerez Y, del Monte-Millan $M$, Massarrah T, et al. Frequency of germline DNA genetic findings in an unselected prospective cohort of triple-negative breast cancer patients participating in a platinum-based neoadjuvant chemotherapy trial. Breast Cancer Res Treat. 2016;156(3):507-15. doi:10.1007/ s10549-016-3792-1.

54. Buleje JL, Huaman F, Guevara-Fujita M, Acosta O, Pinto JA, Araujo J, et al. Detección de reordenamientos genómicos en los genes BRCA1 y BRCA2 en 16 familias peruanas con cáncer de mama mediante Amplificación de Sondas dependiente de Ligamiento Múltiple (MLPA). Carcinos. 2015;5(2):34-8.

55. Delgado L, Fernandez G, Grotiuz G, Cataldi S, Gonzalez A, Lluveras $\mathrm{N}$, et al. BRCA1 and BRCA2 germline mutations in Uruguayan breast and breast-ovarian cancer families. Identification of novel mutations and unclassified variants. Breast Cancer Res Treat. 2011;128(1):211-8. doi:10.1007/s10549-010-1320-2.

56. Lara K, Consigliere N, Perez J, Porco A. BRCA1 and BRCA2 mutations in breast cancer patients from Venezuela. Biol Res. 2012;45(2):117-30. doi:10.4067/S0716-97602012000200003.

57. Easton DF, Pooley KA, Dunning AM, Pharoah PD, Thompson D, Ballinger $D G$, et al. Genome-wide association study identifies novel breast cancer susceptibility loci. Nature. 2007;447(7148):1087-93. doi:1 0.1038/ nature05887.

58. Cox A, Dunning AM, Garcia-Closas M, Balasubramanian S, Reed MW, Pooley KA, et al. A common coding variant in CASP8 is associated with breast cancer risk. Nat Genet. 2007;39(3):352-8. doi:10.1038/ng1981. 
59. Rosa-Rosa JM, Pita G, Urioste M, Llort G, Brunet J, Lazaro C, et al. Genome-wide linkage scan reveals three putative breast-cancersusceptibility loci. Am J Hum Genet. 2009;84(2):115-22. doi:10.1016/j. ajhg.2008.12.013.

60. Stacey SN, Manolescu A, Sulem P, Thorlacius S, Gudjonsson SA, Jonsson $\mathrm{GF}$, et al. Common variants on chromosome $5 \mathrm{p} 12$ confer susceptibility to estrogen receptor-positive breast cancer. Nat Genet. 2008;40(6):7036. doi:10.1038/ng.131.

61. Lavin MF, Birrell G, Chen P, Kozlov S, Scott S, Gueven N. ATM signaling and genomic stability in response to DNA damage. Mutat Res. 2005;569(1-2):123-32. doi:10.1016/j.mrfmmm.2004.04.020.

62. Gonzalez-Hormazabal P, Bravo T, Blanco R, Valenzuela CY, Gomez F, Waugh $\mathrm{E}$, et al. Association of common ATM variants with familial breast cancer in a South American population. BMC Cancer. 2008;8:117. doi:10.1186/1471-2407-8-117.

63. Calderon-Zuniga Fdel C, Ocampo-Gomez G, Lopez-Marquez FC, Recio-Vega R, Serrano-Gallardo LB, Ruiz-Flores P. ATM polymorphisms IVS24-9delT, IVS38-8T>C, and 5557G >A in Mexican women with familial and/or early-onset breast cancer. Salud Publica Mex. 2014;56(2):206-12.

64. Irminger-Finger I. BARD1, a possible biomarker for breast and ovarian cancer. Gynecol Oncol. 2010;117(2):211-5. doi:10.1016/j. ygyno.2009.10.079.

65. Karppinen SM, Barkardottir RB, Backenhorn K, Sydenham T, Syrjakoski K, Schleutker J, et al. Nordic collaborative study of the BARD1 Cys557Ser allele in 3956 patients with cancer: enrichment in familial BRCA1/BRCA2 mutation-negative breast cancer but not in other malignancies. J Med Genet. 2006;43(11):856-62. doi:10.1136/ jmg.2006.041731.

66. Gonzalez-Hormazabal P, Reyes JM, Blanco R, Bravo T, Carrera I, Peralta $\mathrm{O}$, et al. The BARD1 Cys557Ser variant and risk of familial breast cancer in a South-American population. Mol Biol Rep. 2012;39(8):8091-8. doi:10.1007/s11033-012-1656-2.

67. Gonzalez-Hormazabal P, Castro VG, Blanco R, Gomez F, Peralta O, Waugh E, et al. Absence of CHEK2 1100delC mutation in familial breast cancer cases from a South American population. Breast Cancer Res Treat. 2008;110(3):543-5. doi:10.1007/s10549-007-9743-0.

68. Coles BF, Kadlubar FF. Detoxification of electrophilic compounds by glutathione S-transferase catalysis: determinants of individual response to chemical carcinogens and chemotherapeutic drugs? BioFactors. 2003:17(1-4):115-30.

69. Soto-Quintana O, Zuniga-Gonzalez GM, Ramirez-Patino R, Ramos-Silva A, Figuera LE, Carrillo-Moreno DI, et al. Association of the GSTM1 null polymorphism with breast cancer in a Mexican population. Genet Mol Res GMR. 2015;14(4):13066-75. doi:10.4238/2015.October.26.2.

70. Duggan C, Ballard-Barbash R, Baumgartner RN, Baumgartner KB, Bernstein L, McTiernan A. Associations between null mutations in GSTT1 and GSTM1, the GSTP1 Ile(105)Val polymorphism, and mortality in breast cancer survivors. SpringerPlus. 2013;2:450. doi:10.1186/2193-1801-2-450.

71. Wang T, Yu HT, Wang W, Pan YY, He LX, Wang ZY. Genetic polymorphisms of cytochrome P450 and glutathione S-transferase associated with antituberculosis drug-induced hepatotoxicity in Chinese tuberculosis patients. J Int Med Res. 2010;38(3):977-86. doi:10.1177/147323001003800324

72. Jaramillo-Rangel G, Ortega-Martinez M, Cerda-Flores RM, BarreraSaldana HA. Polymorphisms in GSTM1, GSTT1, GSTP1, and GSTM3 genes and breast cancer risk in northeastern Mexico. Genet Mol Res GMR. 2015;14(2):6465-71. doi:10.4238/2015.June.11.22.

73. Possuelo LG, Peraca CF, Eisenhardt MF, Dotto ML, Cappelletti L, Foletto E, et al. Polymorphisms of GSTM1 and GSTT1 genes in breast cancer susceptibility: a case-control study. Revista brasileira de ginecologia e obstetricia: revista da Federacao Brasileira das Sociedades de Ginecologia e Obstetricia. 2013;35(12):569-74.

74. Yin G, Kono S, Toyomura K, Hagiwara T, Nagano J, Mizoue T, et al. Methylenetetrahydrofolate reductase C677T and A1298C polymorphisms and colorectal cancer: the Fukuoka Colorectal Cancer Study. Cancer Sci. 2004;95(11):908-13.

75. Alshatwi AA. Breast cancer risk, dietary intake, and methylenetetrahydrofolate reductase (MTHFR)single nucleotide polymorphisms. Food Chem Toxicol Int J Pub Br Ind Biol Res Assoc. 2010:48(7):1881-5. doi:10.1016/j.fct.2010.04.028.
76. Jiang-Hua Q, De-Chuang J, Zhen-Duo L, Shu-de C, Zhenzhen L. Association of methylenetetrahydrofolate reductase and methionine synthase polymorphisms with breast cancer risk and interaction with folate, vitamin B6, and vitamin B 12 intakes. Tumour Biol J Int Soci Oncodev Biol Med. 2014;35(12):11895-901. doi:10.1007/s13277-014-2456-1.

77. Zara-Lopes T, Gimenez-Martins AP, Nascimento-Filho CH, Castanhole-Nunes MM, Galbiatti-Dias AL, Padovani-Junior JA, et al. Role of MTHFR C677T and MTR A2756G polymorphisms in thyroid and breast cancer development. Genet Mol Res GMR. 2016;15(2). doi:10.4238/gmr.15028222.

78. Lopez-Cortes A, Echeverria C, Ona-Cisneros F, Sanchez ME, Herrera C, Cabrera-Andrade A, et al. Breast cancer risk associated with gene expression and genotype polymorphisms of the folate-metabolizing MTHFR gene: a case-control study in a high altitude Ecuadorian mestizo population. Tumour Biol J Int Soci Oncodev Biol Med. 2015;36(8):6451-61. doi:10.1007/s13277-015-3335-0.

79. Wong AK, Pero R, Ormonde PA, Tavtigian SV, Bartel PL. RAD51 interacts with the evolutionarily conserved BRC motifs in the human breast cancer susceptibility gene brca2. J Biol Chem. 1997;272(51):31941-4.

80. Galkin VE, Esashi F, Yu X, Yang S, West SC, Egelman EH. BRCA2 BRC motifs bind RAD51-DNA filaments. Proc Natl Acad Sci USA 2005;102(24):8537-42. doi:10.1073/pnas.0407266102.

81. Jara L, Acevedo ML, Blanco R, Castro VG, Bravo T, Gomez F, et al. RAD51 $135 \mathrm{G}>\mathrm{C}$ polymorphism and risk of familial breast cancer in a South American population. Cancer Genet Cytogenet. 2007;178(1):65-9. doi:10.1016/j.cancergencyto.2007.05.024.

82. de Moura Gallo CV, Azevedo ESMG, de Moraes E, Olivier M, Hainaut P. TP53 mutations as biomarkers for cancer epidemiology in Latin America: current knowledge and perspectives. Mutat Res. 2005;589(3):192207. doi:10.1016/j.mrrev.2005.01.002.

83. Levine AJ, Oren M. The first 30 years of p53: growing ever more complex. Nat Rev Cancer. 2009;9(10):749-58. doi:10.1038/nrc2723.

84. Giacomazzi J, Graudenz MS, Osorio CA, Koehler-Santos P, Palmero El, Zagonel-Oliveira M, et al. Prevalence of the TP53 p. R337H mutation in breast cancer patients in Brazil. PLoS ONE. 2014;9(6):e99893. doi:10.1371/journal.pone.0099893.

85. Andrade KC, Santiago KM, Fortes FP, Mambelli LI, Nobrega AF, Achatz MI. Early-onset breast cancer patients in South and Southeast of Brazil should be tested for the TP53 p. R337H mutation. Genet Mol Biol. 2016;39(2):199-202. doi:10.1590/1678-4685-GMB-2014-0343.

86. Ribeiro RC, Sandrini F, Figueiredo B, Zambetti GP, Michalkiewicz E, Lafferty AR, et al. An inherited p53 mutation that contributes in a tissuespecific manner to pediatric adrenal cortical carcinoma. Proc Natl Acad Sci USA. 2001;98(16):9330-5. doi:10.1073/pnas.161479898.

87. Achatz MI, Olivier M, Le Calvez F, Martel-Planche G, Lopes A, Rossi BM, et al. The TP53 mutation, R337H, is associated with Li-Fraumeni and LiFraumeni-like syndromes in Brazilian families. Cancer Lett. 2007;245(12):96-102. doi:10.1016/j.canlet.2005.12.039.

88. Palmero El, Schuler-Faccini L, Caleffi M, Achatz MI, Olivier M, MartelPlanche $\mathrm{G}$, et al. Detection of R337H, a germline TP53 mutation predisposing to multiple cancers, in asymptomatic women participating in a breast cancer screening program in Southern Brazil. Cancer Lett. 2008;261(1):21-5. doi:10.1016/j.canlet.2007.10.044.

89. Custodio G, Parise GA, Kiesel Filho N, Komechen H, Sabbaga CC, Rosati R, et al. Impact of neonatal screening and surveillance for the TP53 R337H mutation on early detection of childhood adrenocortical tumors. J Clin Oncol Off J Am Soci Clin Oncol. 2013;31(20):2619-26. doi:10.1200/JCO.2012.46.3711.

90. Seidinger AL, Mastellaro MJ, Paschoal Fortes F, Godoy Assumpcao J, Aparecida Cardinalli I, Aparecida Ganazza M, et al. Association of the highly prevalent TP53 R337H mutation with pediatric choroid plexus carcinoma and osteosarcoma in southeast Brazil. Cancer. 2011;117(10):2228-35. doi:10.1002/cncr.25826.

91. Macias-Gomez NM, Peralta-Leal V, Meza-Espinoza JP, Gutierrez-Angulo M, Duran-Gonzalez J, Ramirez-Gonzalez JM, et al. Polymorphisms of the XRCC1 gene and breast cancer risk in the Mexican population. Fam Cancer. 2015;14(3):349-54. doi:10.1007/s10689-015-9787-y.

92. Jara L, Gonzalez-Hormazabal P, Cerceno K, Di Capua GA, Reyes JM, Blanco R, et al. Genetic variants in FGFR2 and MAP3K1 are associated with the risk of familial and early-onset breast cancer in a SouthAmerican population. Breast Cancer Res Treat. 2013;137(2):559-69. doi:10.1007/s10549-012-2359-z 
93. Murillo-Zamora E, Moreno-Macias H, Ziv E, Romieu I, LazcanoPonce E, Angeles-Llerenas A, et al. Association between rs2981582 polymorphism in the FGFR2 gene and the risk of breast cancer in Mexican women. Arch Med Res. 2013;44(6):459-66. doi:10.1016/j. arcmed.2013.08.006.

94. Elematore I, Gonzalez-Hormazabal P, Reyes JM, Blanco R, Bravo T, Peralta O, et al. Association of genetic variants at TOX3, 2q35 and 8q24 with the risk of familial and early-onset breast cancer in a SouthAmerican population. Mol Biol Rep. 2014;41(6):3715-22. doi:10.1007/ s11033-014-3236-0.

95. Leyton Y, Gonzalez-Hormazabal P, Blanco R, Bravo T, Fernandez-Ramires $\mathrm{R}$, Morales S, et al. Association of PALB2 sequence variants with the risk of familial and early-onset breast cancer in a South-American population. BMC Cancer. 2015;15:30. doi:10.1186/s12885-015-1033-3.

96. Xia B, Sheng Q, Nakanishi K, Ohashi A, Wu J, Christ N, et al. Control of BRCA2 cellular and clinical functions by a nuclear partner, PALB2. Mol Cell. 2006;22(6):719-29. doi:10.1016/j.molcel.2006.05.022.

97. Sy SM, Huen MS, Chen J. PALB2 is an integral component of the BRCA complex required for homologous recombination repair. Proc Natl Acad Sci USA. 2009;106(17):7155-60. doi:10.1073/pnas.0811159106.

98. Zhang F, Ma J, Wu J, Ye L, Cai H, Xia B, et al. PALB2 links BRCA1 and BRCA2 in the DNA-damage response. Curr Biol CB. 2009;19(6):524-9. doi:10.1016/j.cub.2009.02.018.

99. Zhang F, Fan Q, Ren K, Andreassen PR. PALB2 functionally connects the breast cancer susceptibility proteins BRCA1 and BRCA2. Mol Cancer Res MCR. 2009;7(7):1110-8. doi:10.1158/1541-7786.MCR-09-0123.

100. Sy SM, Huen MS, Zhu Y, Chen J. PALB2 regulates recombinational repair through chromatin association and oligomerization. J Biol chem. 2009;284(27):18302-10. doi:10.1074/jbc.M109.016717.
101. Pharoah PD, Antoniou A, Bobrow M, Zimmern RL, Easton DF, Ponder BA Polygenic susceptibility to breast cancer and implications for prevention. Nat Genet. 2002;31(1):33-6. doi:10.1038/ng853.

102. Nathanson KL, Wooster R, Weber BL. Breast cancer genetics: what we know and what we need. Nat Med. 2001;7(5):552-6. doi:10.1038/87876.

103. Wooster R, Weber BL. Breast and ovarian cancer. New Engl J Med. 2003:348(23):2339-47. doi:10.1056/NEJMra012284.

104. Homburger JR, Moreno-Estrada A, Gignoux CR, Nelson D, Sanchez E, Ortiz-Tello P, et al. Genomic insights into the ancestry and demographic history of South America. PLoS Genet. 2015;11(12):e1005602. doi:10.1371/journal.pgen.1005602.

105. Salzano FM, Sans M. Interethnic admixture and the evolution of Latin American populations. Genet Mol Biol. 2014;37(1 Suppl):151-70.

106. Morera B, Barrantes R, Marin-Rojas R. Gene admixture in the Costa Rican population. Ann Hum Genet. 2003;67(Pt 1):71-80.

107. Wang Z, Hildesheim A, Wang SS, Herrero R, Gonzalez P, Burdette L, et al. Genetic admixture and population substructure in Guanacaste Costa Rica. PLoS ONE. 2010:5(10):e13336. doi:10.1371/journal.pone.0013336.

108. Moreno-Estrada A, Gignoux CR, Fernandez-Lopez JC, Zakharia F, Sikora $M$, Contreras AV, et al. Human genetics. The genetics of Mexico recapitulates Native American substructure and affects biomedical traits. Science. 2014;344(6189):1280-5. doi:10.1126/science.1251688.

109. Alter BP, Rosenberg PS, Brody LC. Clinical and molecular features associated with biallelic mutations in FANCD1/BRCA2. J Med Genet. 2007:44(1):1-9. doi:10.1136/jmg.2006.043257.

\section{Submit your next manuscript to BioMed Central and we will help you at every step:}

- We accept pre-submission inquiries

- Our selector tool helps you to find the most relevant journal

- We provide round the clock customer support

- Convenient online submission

- Thorough peer review

- Inclusion in PubMed and all major indexing services

- Maximum visibility for your research

Submit your manuscript at www.biomedcentral.com/submit
() Biomed Central 